\title{
Ultrastructure of the microsporidian Inodosporus octospora (Thelohaniidae), a parasite of the shrimp Palaemon serratus (Crustacea, Decapoda)
}

\author{
C. Azevedo ${ }^{1, *}$, L. Corral ${ }^{1}$, C. P. Vivarès ${ }^{2}$ \\ ${ }^{1}$ Department of Cell Biology, Institute of Biomedical Sciences and Center of Marine and Environmental Research, \\ University of Oporto, Lg. A. Salazar no. 2, 4099-003 Porto, Portugal \\ ${ }^{2}$ Laboratoire de Biologie Comparée des Protistes, Université Blaise Pascal-Clermont II, 63177 Aubière, France
}

\begin{abstract}
A parasite of the muscle of the shrimp Palaemon serratus has been examined by light and electron microscopy. Development occurs among myofibrils and induces ultrastructural alterations of the muscle fibers causing white discoloration. This microsporidian is characterized by uninucleate, later diplokaryotic and di-diplokaryotic meronts. The mother cell develops by rosette-like budding into 8 uninucleate sporoblasts, each containg 3 tape-like filaments attached to the wall that is enclosed in a persistent sporophorous vacuole. Each sporoblast gives rise to a uninucleate spore that possesses 3 elongated tape-like filaments attached to the spore wall, like spore tails. The morphological characters of the spores, redescribed in the present study, suggested that the spores belonged to Inodosporous octospora. The possibility that in the future members of Inodosporus sp. may be considered a new parasite group is discussed.
\end{abstract}

KEY WORDS: Ultrastructure $\cdot$ Microsporidian $\cdot$ Inodosporus octospora $\cdot$ Parasite $\cdot$ Shrimp

\section{INTRODUCTION}

A review of the available literature revealed that microsporidian species can infect decapod crustaceans (Sprague 1977, Sprague et al. 1992, Larsson 1999), parasitizing the skeletal muscle (Codreanu 1966, Codreanu \& Balcescu-Codreanu 1974, Codreanu et al. 1974, Overstreet \& Weidner 1974). Some shrimp species common and abundant in the North Atlantic and of economic interest in this region are parasitized by microsporidian species.

A microsporidian with tailed spores was first reported in Palaemon serratus from the Atlantic coast and named Thelohania octospora (see Pixell-Goodrich 1920). Later, in P. elegans from the Black Sea, a microsporidian of the same species was described (Codreanu, 1966). Some years later, another similar microsporidian in $P$. serratus from the French coast was described as belonging to the genus Orthothelohania (Codreanu et al. 1974). This genus had previously been created by Codreanu \& Balcescu-Codreanu (1974), but was later

\footnotetext{
•E-mail: azevedoc@icbas.up.pt
}

considered to be a synonym of Thelohania (Sprague 1970).

Ultrastructural studies showing spore tails in the microsporidian parasite of the shrimp Paleomonetes pugio from Mississippi (USA) resulted in the creation of a new genus, Inodosporus, and simultaneously, a new species, I. spraguei (Overstreet \& Weidner 1974). Simultaneously Thelohania octospora was transferred to the genus Inodosporous as I. octospora (Overstreet \& Weidner 1974).

The genus Inodosporus was created within the family Nosematidae with the following characteristics: a mother cell that develops into 8 sporoblasts and subsequently into 8 spores, each one possessing 3 or rarely 4 elongated external appendages (spore tails) and a pansporoblast with a persistent membrane (Overstreet \& Weidner 1974). Later, the genus Inodosporus was placed in the family Thelohaniidae (Sprague et al. 1992)

The purpose of the present study is to redescribe the ultrastructure, life cycle stages and tailed spores of Inodosporus octospora and to compare these with other species in the same genus. 


\section{MATERIALS AND METHODS}

Specimens of the shrimp Palaemon serratus (Crustacea, Decapoda) containing white discoloured muscles were collected on the French Atlantic coast (northern Brittany) and Portuguese Atlantic coast (near Oporto). For light microscopy, small fragments of infected muscles were macerated in saline aqueous solution and examined using phase-contrast microscopy. The presence of spores was determined by examining smear preparations fixed in methanol and stained by methylene blue.

Material for transmission electron microscopy (TEM) was dissected out of muscle, fixed in $3 \%$ glutaraldehyde in $0.2 \mathrm{M}$ cacodylate buffer $(\mathrm{pH} 7.4)$ at $4^{\circ} \mathrm{C}$ for $3 \mathrm{~h}$, rinsed in the same buffer, post-fixed in $2 \%$ osmium tetroxide in the same buffer at $4^{\circ} \mathrm{C}$ for $3 \mathrm{~h}$, dehydrated in a graded ethanol series, transferred to propylene oxide and embedded in Epon. Semithin sections $(1 \mu \mathrm{m})$ were stained with toluidine blue and observed by light microscopy (LM). Ultrathin sections were contrasted with aqueous uranyl acetate and lead citrate and observed using a JEOL 100CXII transmission electron microscope at $60 \mathrm{Kv}$.

\section{RESULTS}

Infected adult specimens of the shrimp were easily distinguished from normal specimens by the localization of a white zone in the muscle of both sexes.

\section{Light microscopy}

Mature spores observed in fresh smears measured 2.6 (2.4 to 2.8$) \mu \mathrm{m} \times 1.3(1.2$ to 1.5$) \mu \mathrm{m}$. Sporophorous vacuoles with a persistent membrane containing 8 spores were observed by LM (Fig. 1). Examination of semithin muscle sections revealed heavy microsporidian infection with different life cycle stages present (Fig. 2). The parasite occurred in clusters in each mus- cle fascicle where necrosis and complete disorganization of the myofibrils were evident (Fig. 2). Some macrospores about 3.8 (3.5 to 4.2 ) $\mu \mathrm{m}$ by 2.4 (2.0 to 2.9) $\mu \mathrm{m}(\mathrm{n}=25)$ were observed among more numerous smaller spores (Fig. 2). The spores (total 8) were contained in a sporophorous vacuole as observed in serial semithin sections.

\section{Transmission electron microscopy}

All stages of sporogenesis were among muscle myofibrils. Serial ultrathin sections revealed various life cycle stages and mature sporoblasts and spores surrounded by a persistent sporophorous vacuole membı ane.

\section{Meronts}

The early stages of merogony localized among muscle myofibrils comprised uninuclear cells. These meronts exhibited an irregular and thick plasmalemma contour. The cytoplasm showed mainly free ribosomes while the nuclei showed little chromatin and often a nucleolus (Fig. 3). Later, the uninucleate meronts became diplokaryotic. These cells were delimited by a thin plasmalemma and contained cytoplasm with free ribosomes and rough endoplasmic reticulum (RER). The nuclei had irregular contours. The host cytoplasm contained numerous small vesicles in close contact with the diplokaryon plasmalemma (Fig. 4).

\section{Sporonts}

It was sometimes possible, in favorable ultrathin sections, to visualize some early sporonts containing 2 diplokarya (tetranuclear sporonts). These cells were distinct from meronts as they possessed a thickened plasmalemma of $15 \mathrm{~nm}$ (Fig. 5). Later, the differen-

Figs. 1 to 7. Life cycle stages of the parasite Inodosporus octospora, from Paleamon serratus. Fig. 1. Two sporophorous vacuoles each containing 8 spores observed by LM. $\times 590$. Fig. 2. Semithin section showing numerous spores (S) among muscle fibers $(*)$. $\times 480$. Fig. 3. Ultrathin section of a uninucleate meront in direct contact with its host cell (*). The nucleus (N) contains little visible chromatin and a small nucleolus (Nc). In the cytoplasm (C), a large quantity of free ribosomes are visible. $\times 30000$. Fig. 4 . Ultrathin section showing some diplokaryotic meronts in direct contact with the host cytoplasm. Nearby, some muscle fibers (*) and mature spores $(\mathrm{S})$ are present. $\times 9500$. Fig. 5 . A young sporont with 2 diplokarya (tetranucleated) (N) showing early development of the sporophorous vacuole situated in a granular area among muscle fibers (*). $\times 18600$. Inset: Detail of the early development of the sporophorous vacuole (arrow), in contact with the sporont $(\mathrm{Sr})$ and muscle fibers $(*) . \times 22900$. Fig. 6 . Diplokaryotic sporont showing the beginning of the sporophorous vacuole (PV), where granular masses are visible. The cytoplasm of the sporont shows several small vesicles and cisternae. Some muscle fibers are visible nearby (*). N: nucleus. $\times 32$ 000. Fig. 7. Detail of the sporont periphery showing the cytoplasm with great development of the endoplasmic reticulum cisternae and vesicles (arrows). The sporophorous vacuole (PV) shows several granular masses. $\times 38000$ 


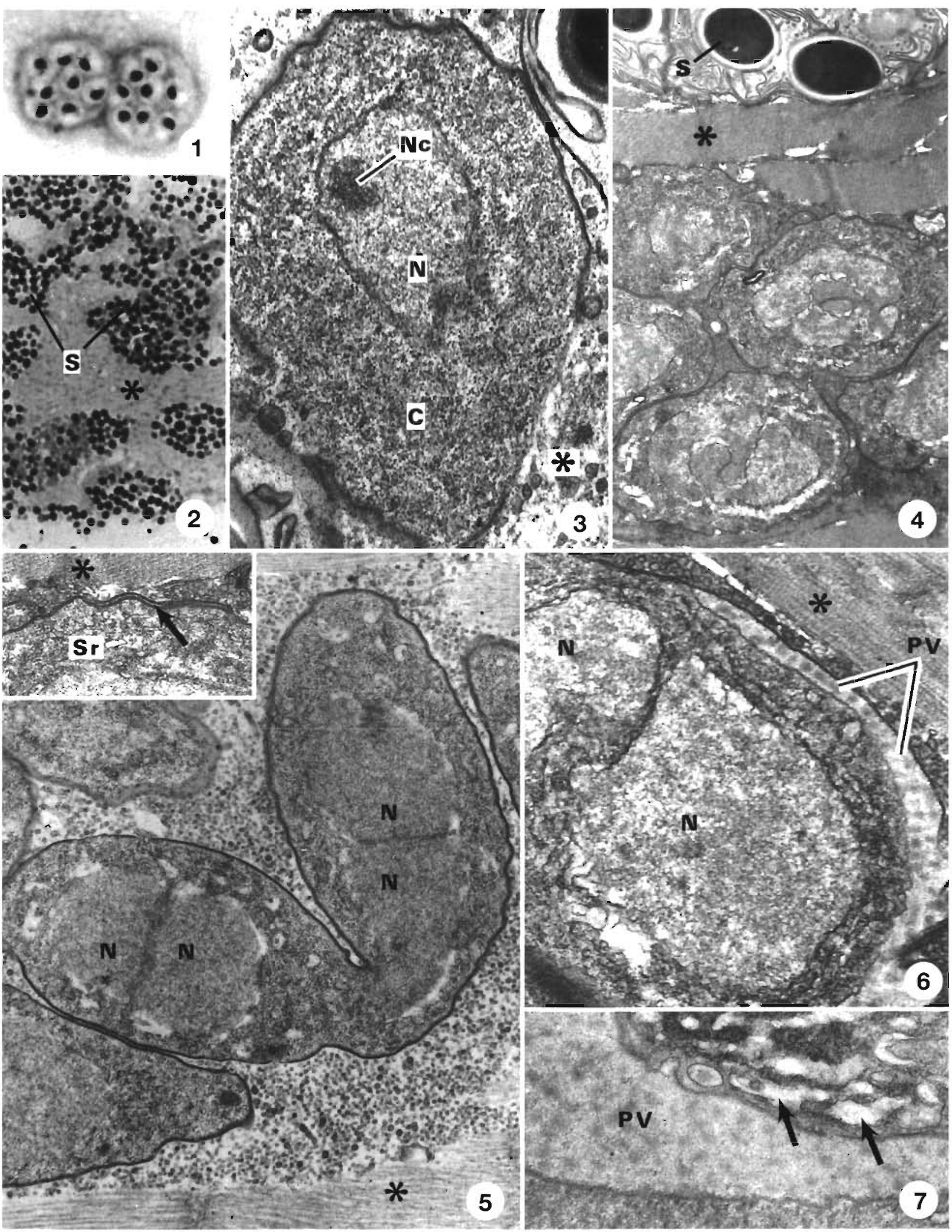


tiation of a parallel membrane, which became the sporophorous membrane, was observed (Figs. 6 \& 7). The sporonts showed lobed forms in contact with the host myofibrils where ultrastructural disorganization was observed (Fig. 5). In favorable sections, it was possible to observe the appearance of a parallel membrane in the sporont cytoplasm in close contact with the plasmalemma (Fig. 5, inset). During this stage the sporophorous vacuole became visible. A granular metabolic product that seemed to be exported by RER was seen between the 2 parallel membranes (Figs. $6 \& 7$ ).

Sporogony proceeded by budding, the first stage being characterized by the separation of diplokaryotic nuclei (Fig. 6) into a rosette of sporonts (Fig. 8). Nuclear division was signaled by the appearance of dense spindle pole bodies. During karyokinesis the nuclei had an irregular form (Fig. 8). Sporogenesis began at the time of separation of the sporonts. Each nucleus with its surrounding cytoplasm and plasmalemma became a sporoblast (Fig. 9).

\section{Sporoblasts}

In the final phase of the sporont, cytokinesis gave rise to 8 uninucleate sporoblasts within the sporophorous vacuole. In ultrathin sections the maximum number of sporoblasts observed was 6 , whereas serial ultrathin sections revealed the presence of a maximum of 8 sporoblasts.

During early development of the sporoblast outer surface, tape-like filaments (TLF) became visible in close contact with the sporoblast surface within the sporophorous vacuole (Figs. $9 \& 10$ ). Simultaneously, an extramembranous coat developed as an initial step in sporoblast wall formation. Gradually, the TLF became very long and seemed to coil around the sporoblasts (Figs. 11 \& 12). At their basal insertion, they were conical and contained granular material, similar to the matrix of the sporophorous vacuole (Figs. $9 \& 10$ ).

When sections were favorable, it was possible to observe that the TLF were continuous with an external exospore surrounding the wall (Figs. 10 to 12). In ultrathin serial sections, we have observed 1 TLF at the anterior end and 2 in lateral positions at the posterior end of the sporoblast. During the final phase of sporoblast maturation the TLF became more evident and finally gave rise to spore tails.

As happens with most microsporida, spore development is a complex process that seems to proceed very quickly, giving rise to the anchoring disc, the polar filament and the posterior vacuole.

\section{Spores}

In serial ultrathin sections, 8 spores were observed within each sporophorous vacuole, although the number varied depending upon the plane of sectioning (Fig. 13). Spores had an ellipsoidal shape and were 2.5 (2.0 to 2.7$) \mu \mathrm{m} \times 1.3(1.0$ to 1.5$) \mu \mathrm{m}(n=25)$. The thick spore wall comprised a thin exospore and an electrolucent endospore -30 nm thick (Figs. 13 to 15). Three, long, external spore tails were attached, 1 at an eccentric anterior position and the other 2 at lateral positions at the base of the spore wall. They were irregularly coiled in the same sporophorous vacuole (Figs. $14 \& 15$ ). Internally the spores were uninucleate and the nucleus occupied a central position between the polaroplast and the posterior vacuole. The polaroplast (Fig. 15) was a typical extrusion apparatus composed of the apical anchoring disc and the polar filament. The latter was arranged in a single row of coils with 5 or 6 turns and it was about $46 \mu \mathrm{m}$ long. Ribosomes were irregularly distributed around the nucleus (Figs. $14 \& 15$ ).

No significant morphological differences were observed in parasites of shrimp from the 2 Atlantic coasts. In serial ultrathin sections it was possible to observe different life cycle stages (drawn in Fig. 16), including mature spores morphology (drawn in Fig. 17) simultaneously.

\section{DISCUSSION}

All the LM and TEM data was easily interpreted by comparison with the ultrastructural characteristics of Microsporida (Vávra 1976, Sprague et al. (1992), Larsson 1999). Most of our results, and especially those regarding the presence of spore tails, are coincident

Figs. 8 to 13. Ultrathin sections of different life cycle stages of Inodosporus octospora. Fig. 8. Sporophorous vacuole (PV) containing a dividing rosette sporont with nuclei ( $N$ ), some of which seem to be in nucleokinesis (arrows). The sporophorous vacuole is among muscle fibrils (*). $\times 19200$ Fig. 9 . Sporoblasts (Sb) showing the beginning of the formation of tape-like filaments (F) in direct contact with sporoblast walls, and within the sporophorous vacuole (PV). $\times 20300$. Figs. $10 \& 11$. Two sequential phases in the development of tape-like filaments $(F)$ attached to the sporoblast wall. $\times 26300_{i} \times 30300$, respectively. Fig. 12 . General view of sporoblasts contained in sporophorous vacuoles. In favorable sections, it is possible to observe the attachment of the tape-like filaments to the sporoblast wall (arrows) and different tape-like filament sections (F). Sb: sporoblasts $\times 19800$. Fig. 13. Sections of some mature spores $(S)$ showing the tape-like filament $(F)$ insertion (arrows) in the wall. $\times 10600$ 


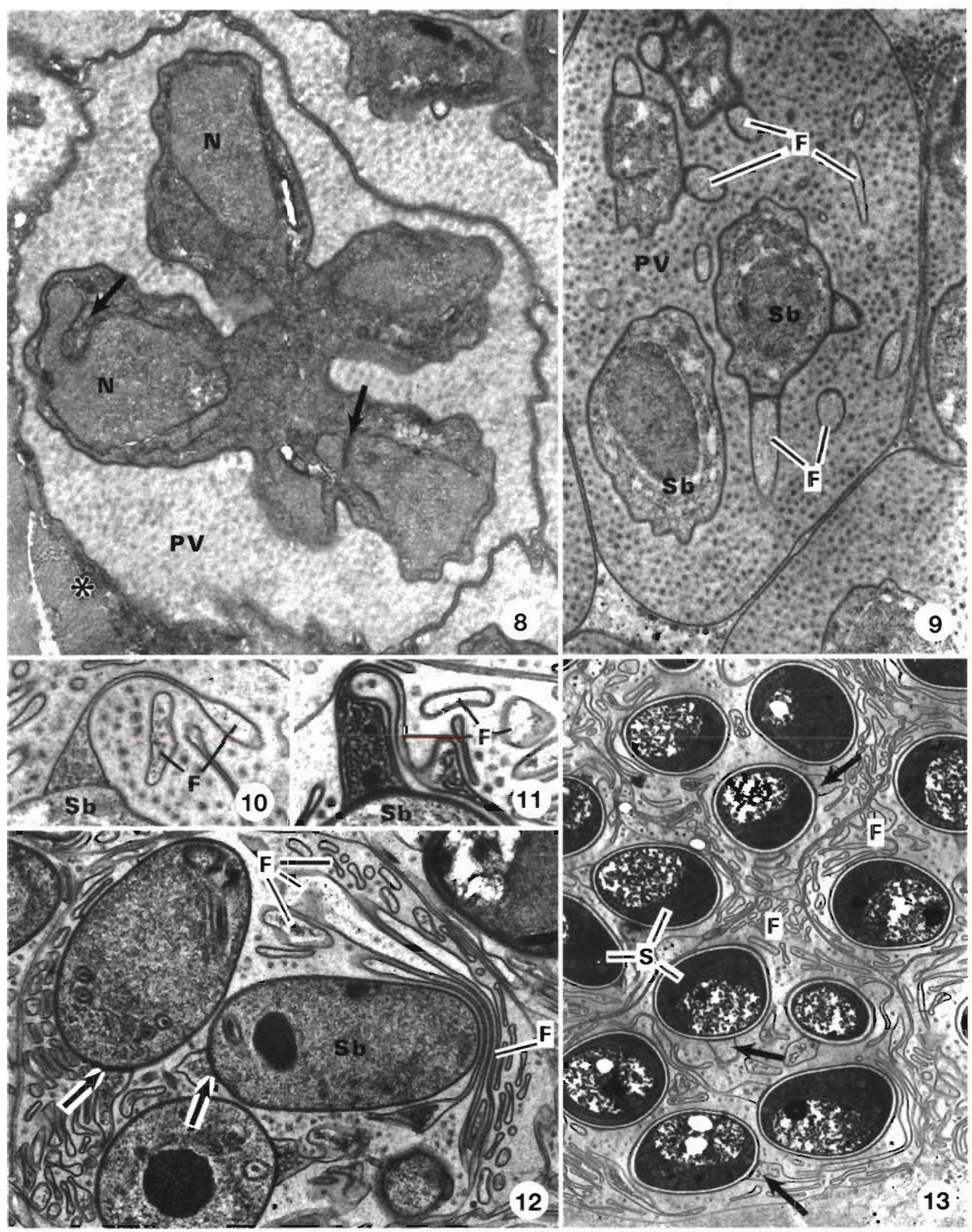




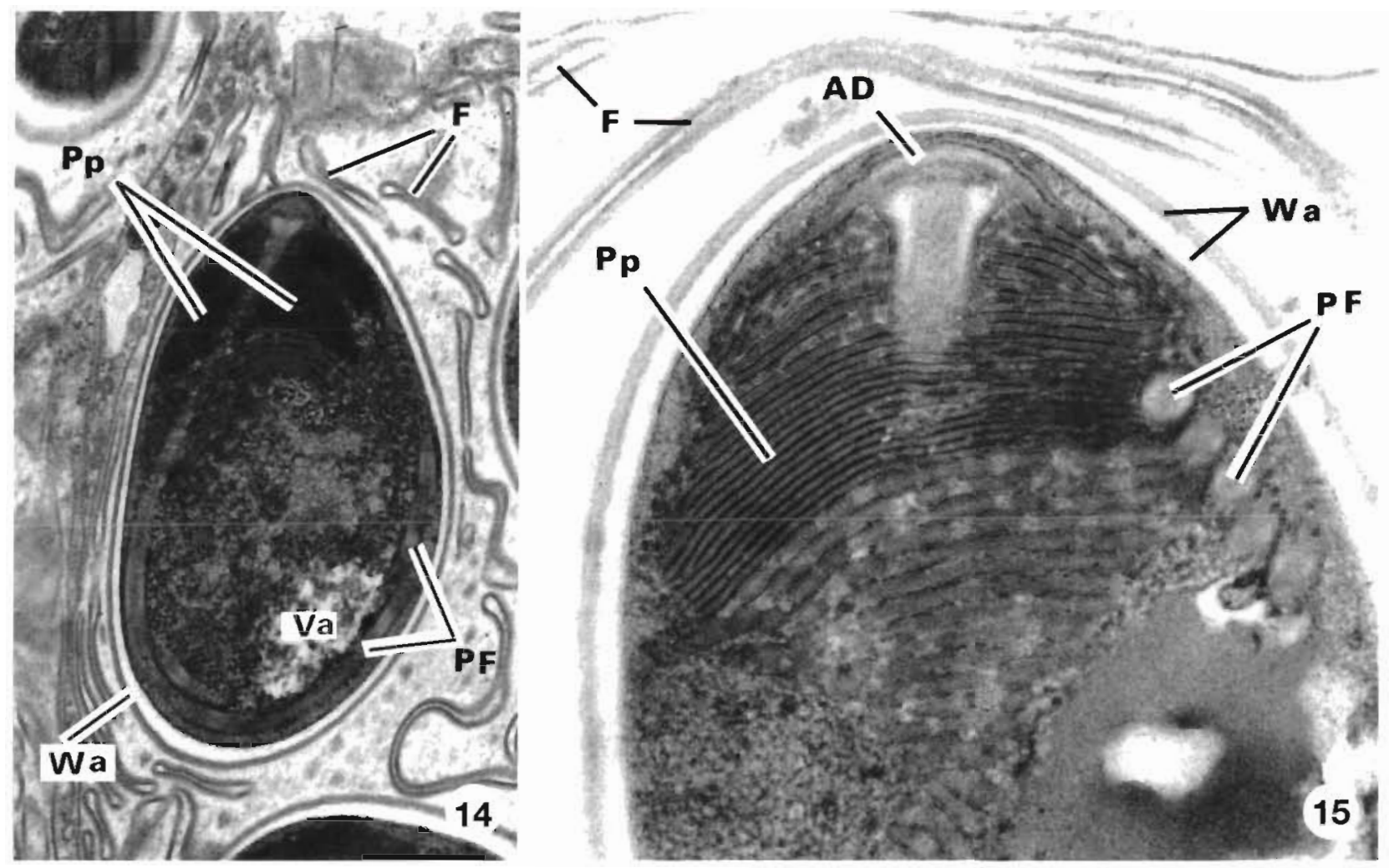

Figs. $14 \&$ 15. Two ultrathin sections of mature spores. Fig. 14. A longitudinal section of a mature spore showing the wall (Waj and different sections of the tape-like filaments $(\mathrm{F})$, polar filament $(\mathrm{PF})$, polaroplast $(\mathrm{Pp})$ and a basal vacuole $($ Va). $\times 32000$. Fig. 15. Ultrastructural detail of the apical region of a mature spore showing the wall (Wa), some sections of the tape-like filaments $(F)$, anchoring disc $(A D)$, polar filament $(P F)$, and polaroplast $(\mathrm{Pp}), \times 72800$

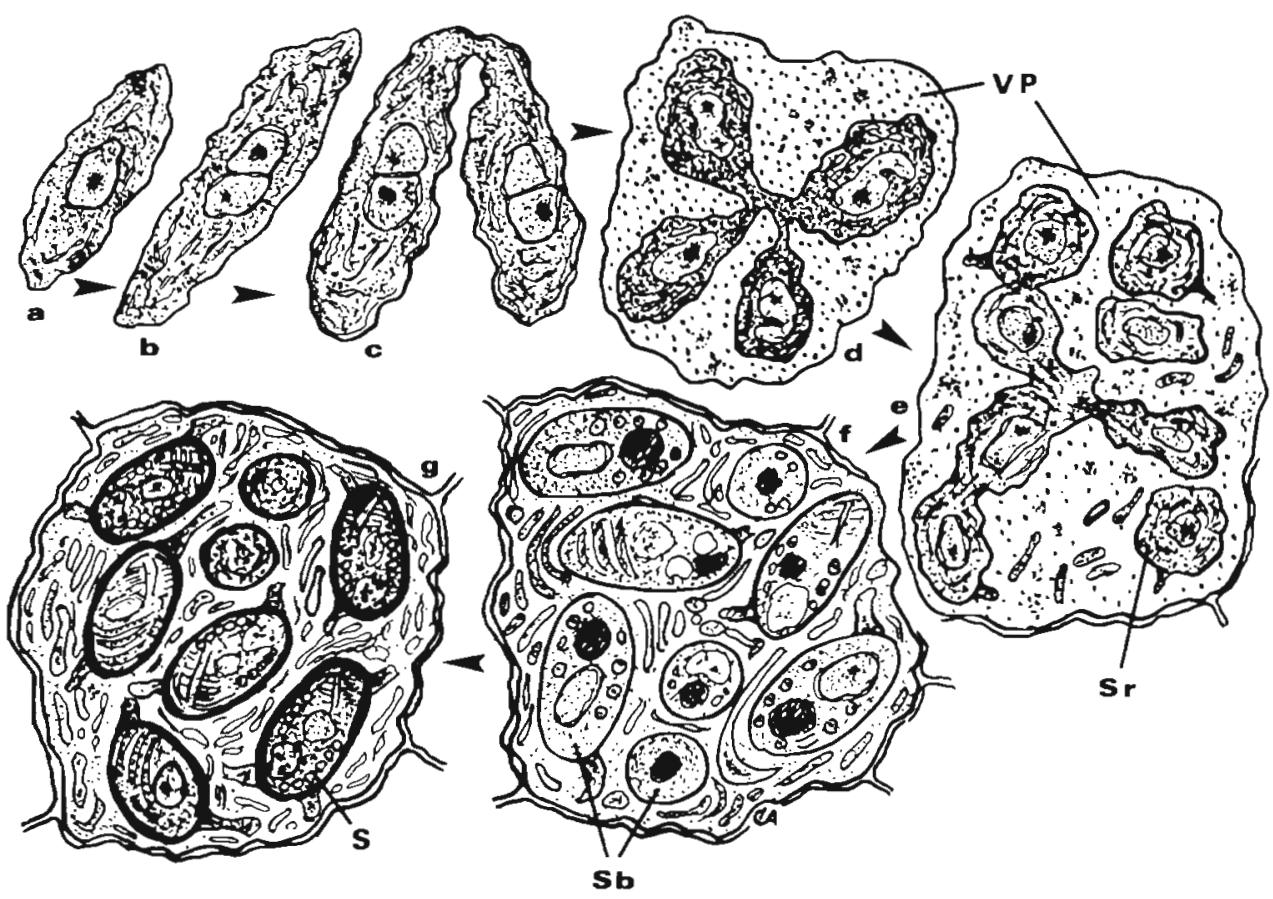

Fig. 16. Schematic drawing of the life cycle of Inodosporus octospora. (a) Uninucleated sporont; (b) diplokaryotic sporont; (c) dividing sporont with 2 diplokarya; (d) dividing sporonts; (e) early sporoblasts; (f) vacuole with 8 sporoblasts; and (g) sporophorous vacuole with 8 spores. Sb: sporoblasts; S: spores; Sr: sporonts; PV: sporophorous vacuole 


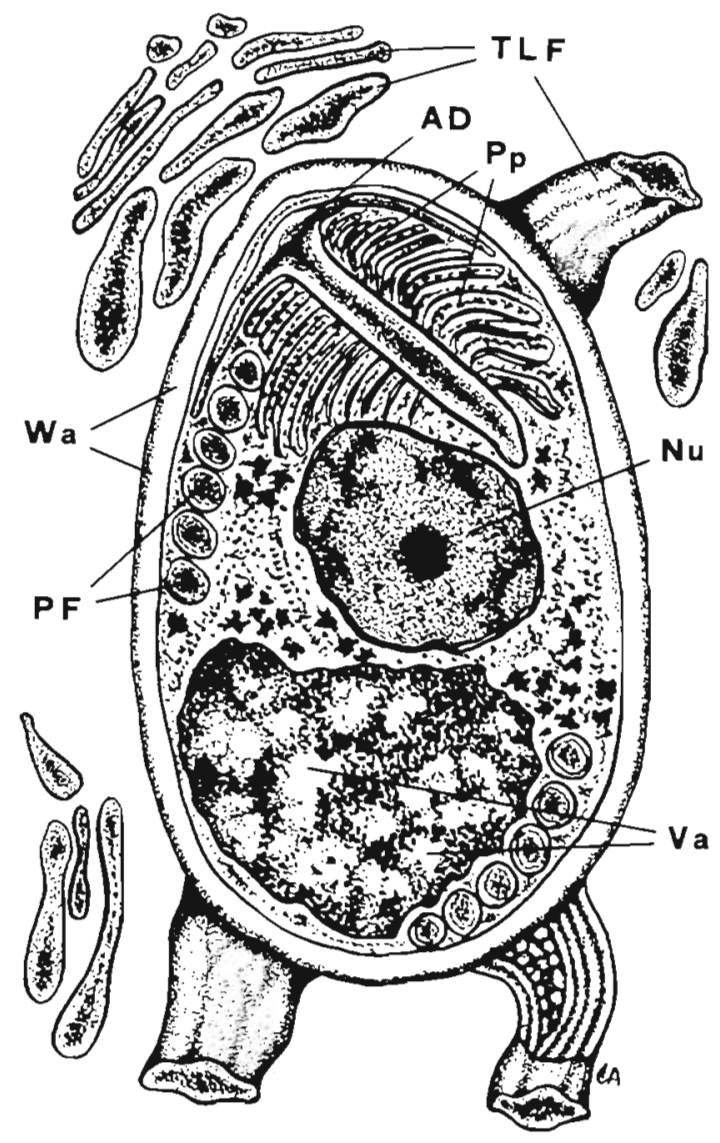

Fig. 17. Schematic drawing of the mature spore of Inodosporus octospora. TLF: different sections of tail-like filaments; AD: anchoring disc; Pp: polaroplast; Wa: wall; PF: polar filament; Nu: nucleus; Va: vacuole

with the morphology and ultrastructural data described previously for Thelohania octospora (Pixell-Goodrich 1920, Codreanu 1966, Codreanu \& Codreanu-Balcescu 1974, Vivarès 1975).

Pixell-Goodrich (1920) was the first to describe the tailed-spores in Thelohania octospora, a parasite of Palaemon serratus from the English Channel. Later, a microsporidian was described in $P$. elegans from the Black Sea as being the same species, but with tailed spores possessing basal appendages only (Codreanu 1966). Unfortunately, the lack of micrographs or drawings to accompany the latter description did not permit any comparison with previous or present results. Based on the presence of 8 sporoblasts per sporophorous vacuole and spores possessing 3 or 4 spore tails, a new genus Inodosporus was created simultaneously with the new species $I$. spraguei, in the family Nosematidae (Overstreet \& Weidner 1974). However, Hazard \& Oldacre (1975) later moved the genus Inodosporus to the family Thelohaniidae (Sprague et al. 1992) because of its octosporoblastic sporogony. This family is a heterogeneous group which needs to be subdivided after a deeper knowledge of the various types of species has been acquired (Sprague 1982). The presence of a sporophorous vacuole containing spores would clearly separate Inodosporous sp. from the family Nosematidae (sub-order Apansporoblastina), because members of this family develop sporogony typically in direct contact with the host cell cytoplasm (Sprague 1982).

In a recent review Larsson (1999) used the term sporophorous vesicles to describe a more or less persistent sac-like structure containing a specific number of spores. In the present work, as in other described species (Azevedo 1987, Sprague et al. 1992), we have used the term vacuole instead of vesicle, frequently used in other works (see Larsson 1999), because we think it is ultrastructurally more correct. The number, origin, position, ultrastructure and insertions of the tails in the spore wall requires more study since these features seem to cause taxonomic and systematic confusion. However, it seems premature in this manuscript to propose a new family to include genera with tailed spores. We suggest that all future studies of species with tailed spores should include TEM and SEM imaging so that it will be possible to compare the nature of the association between spore walls and tails, an important generic taxonomic character (Overstreet \& Weidner 1974)

Acknowledgements. This study was partially supported by the Eng ${ }^{\circ}$. A. Almeida Foundation (Porto-Portugal). The authors thank Mr J. Carvalheiro for the ichonographic work.

\section{LITERATURE CITED}

Azevedo $C$ (1987) Fine structure of the microsporidan Abelspora portucalensis gen. n., sp. n. (Microsporida) parasite of the hepatopancreas of Carcinus maenas (Crustacea, Decapoda). J Parasitol 49:83-92

Codreanu R (1966) On the occurrence of spore or sporont appendages in the Microsporidia and their taxonomic significance. In: Corradetti A (ed) Proceedings of the 1st International Congress of Parasitology, Roma. Pergamon Press, New York, p 602-603

Codreanu R, Balcescu-Codreanu D (1974) On the morphology and ultrastructure of the microsporidian Thelohania octospora Henneguy, 1892, parasitic in the prawn Palaemon serratus (Pennant) 1777 from the Atlantic French coast; need for a revision of its taxonomic status. In: Proceedings of the 3rd International Congress of Parasitology, München, Vol 1. Facta Publications, Vienna, p 15-16

Codreanu R, Codreanu-Balcescu D, Porchet-Hennéré E (1974) Caractéres ultrastructuraux dans la sporogenèse d'une Microsporidie de type thélohanien parasite musculaire de la crevette Palaemon serratus des côtes de France. C R Acad Sci Paris 279:2047-2049

Hazard EI, Oldacre SW (1975) Revision of Microsporidia (Protozoa) close to Thelohania, with descriptions of one new family, eight new genera and thirteen new species. US Dept Agric Tech Bull 1530:1-104 
Larsson JIR (1999) Identification of Microsporidia. Acta Protozool 38:161-197

Overstreet RM, Weidner E (1974) Differentiation of microsporidian spore tails in Inodosporus spraguei gen. et $\mathrm{sp} . \mathrm{n}$. Z Parasitenkd 44:169-186

Pixell-Goodrich HLM (1920) The spore of Thelohania. Arch Zool 59:17-19

Sprague V (1970) Taxonomy of microsporidia. J Parasitol 56 (2) (Part I) 327

Sprague V (1977) Systematics of the Microsporidia. In: Bulla LA, Cheng TC (eds) Comparative pathobiology, Vol 2. Plenum Press, New York, p 1-510

Editorial responsibility: Timothy Flegel,

Bangkok, Thailand
Sprague V (1982) Microspora. In: Parker SP (ed) Synopsis and classification of living organisms, Vol 2. MacGraw-Hill Company, New York, p 589-594

Sprague V, Becknel JJ, Hazard EI (1992) Taxonomy of phylum Microspora. Crit Rev Microbiol 8:285-395

Vávra J (1976) Structure of the Microspora. In: Bulla LA, Cheng TC (eds) Comparative pathology, Vol 1. Academic Press, New York, p 1-85

Vivarès CP (1975) Étude comparative faite en microscopies photonique et espèces de microsporidies appartenant au genre Thelohania Henneguy, 1892, parasites de crustacés des décapodes marins. Ann Sci Nat Zool Paris 17:141-178

Submitted: May 12, 1999; Accepted: January 25, 2000

Proofs received from author(s): May 29, 2000 